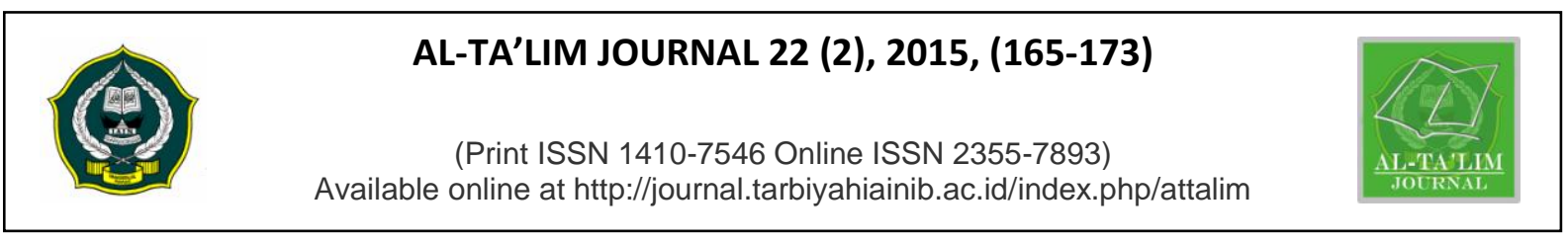

\title{
The Education in Local Islamic Culture of Maulid Nabi Traditions: a Case Study in Nurul Yaqin Ringan-Ringan Pakandangan Padang Pariaman Boarding School
}

\author{
Ahmad Rivauzi \\ Universitas Negeri Padang \\ e-mail : ahmadrivauzi_unp@yahoo.co.id \\ DOI: http://dx.doi.org/10.15548/jt.v22i2.132
}

Received: 7th April 2015; Revised: 10th June 2015; Accepted: 12th July 2015

\begin{abstract}
A wave of globalization encourages intercultural contact more rapidly. This led to an integration between the new values with the old ones that occur outside as well as inside the organization. This encourages the fusion of process and haziness value, even the erosion of the original values of the previously sacred and the identity of a nation. This paper focus on the tradition of Maulid Nabi as one of the local Islamic traditions in Nurul Yaqin Ringan-Ringan Pakandangan Padang Pariaman Boarding School. The tradition of the Maulid Nabi (Prophet's birthday) is a particular religious practice as a result of the grounding the normative teachings of Islam into reality. Education through local Islamic culture is needed by a community in order to have resilience and ability to acquire the significance life such as found in the Nurul Yaqin Ringan-Ringan Pakandangan Pariaman Boarding School's community.
\end{abstract}

Keyword : Education, Local Islamic culture, and Warnings Birth of the Prophet

\section{INTRODUCTION}

According to Sofyan Sauri (2009), acceleration of information due to the wave of globalization encourages the intercultural contact more rapidly. This caused an integration between the new values with the old values that occur outside as well as inside an organization. In addition, one of the major trends that accompany the globalization wave is homogenization (cultural uniformity), instead of neoliberalisation that penetrating all aspects of life, including education. Information and Communication Technology (ICT), which are now increasingly sophisticated has removed the boundaries of space and time so that the world seems to converge in a global village (global village) and united by a global culture that is based on the values of liberal-capitalistic. Exchange of information including transnational value that goes fast and dynamics, encourages the fusion of process and haziness value, even the erosion of the original values of the previously sacred and the identity of a nation. This will affect the process of driving the cultural values of society, which led to a split and the uncertain value. Uncertain values that experienced by a human society is occur because they prefer to use the sense ability, marginalize the role of transcendental values and follow the idea of individualism and capitalism. As a result, humans lose the spirit of humanity and empty of spiritual values so that they have lost meaning life.

In this context, the education through cultural values based on the moral values of society, and transcendental values derived from the religion are very important. This paper discussed a type of education through local Islamic culture in Pesantren Nurul Yaqin 
Ringan-Ringan Pakandangan Padang Pariaman Boarding School.

The focus of the discussion in this paper is a traditional form of Maulid Nabi as one of the local Islamic traditions in Nurul Yaqin Ringan-Ringan Pakandangan Padang Pariaman Boarding School which is one form of education through culture that took place in the society.

This is a qualitative research, which is concerned with the meaning and interpretation. Interpretive approach was derived from studies of literature and hermeneutics, and is concerned with the critical evaluation of texts (Jane Stokes, 2006: xi). Qualitative research can also be defined as a research that produces descriptive data about the words spoken or written, and behavior that can be observed from those studied (Steven J. Tailor and Robert Bogdan, 1984: 5). Researching the tradition in Nurul Yaqin Boarding School, the author used Phenomenology, Social Interaction, and ethnometodology approaches.

\section{Phenomenology}

approach

(phenomenology) has a long history in philosophy and sociology, learning how the social life takes place and see the social behavior - which includes what is said and done - as a result of how people define their world (Bagong Suyanto and Sutinah, 2005: 167). Phenomenology believes that any knowledge about ourselves and the world must necessarily begin with the most personal human experience. William James called it radical empiricism. And also, according to James, is experienced-not interpretations. Phenomenology requires participation, empathy, sympathy of the researchers to study the object. As it has been done by Wilfred Cantwell Smith orientalist in view of Islam. He said, "an observation of Islam can only be justified if the Muslims themselves justify (Annemarie Schimmel, 1997: 11). Symbolic interaction approach holds that all human behavior basically have social meanings (meanings social). Then the social meanings of human behavior attached to the surrounding world is important to understand. Taylor and
Bogdan develop three premises in this regard, they are: (1) Humans act against something (people) based on how they make sense of something (people) are; (2) 'meanings' or the meaning of a social product that emerges from social interaction; and (3) "Social actors' give meaning through a process of interpretation (Steven J. Tailor and Robert Bogdan, 1984: 910). While ethnometodology approach refers to the problem area studied, which is about how individuals create and understand their everyday life. In this regard, it is important to understand how the people in boarding see, explain, and describe the world if their life. Thus, the emphasis is the real thing and it is according to the seen and known. This approach focuses on the micro problems and the researchers is like a photographer (Bagong Suyanto and Sutinah, 2005: 167).

\section{DISCUSSION}

Nurul Yaqin boarding school was built in 1960 AD. Some other sources explained that Nurul Yaqin Boarding school establishment in 1961. According to Syekh Muhammad Rais Tuanku Labai's information, Nurul Yaqin was built in 1960. But Tuanku Labai also confirmed the information in the society that Nurul Yaqin has stand since 1961.

In documents of El-Imraniyah Islamic Education Foundation, as an institution that houses Nurul Yaqin Boarding School explained that in 1960 Syekh Ali Imran returned to Ringan-Ringan and established a boarding school which is now known as the Nurul Yaqin Boarding School. The boarding school was established on March 28, 1961officially.

Based on the description above, it can be concluded that in 1960, Syekh Ali Imran has been set up and carry out the education in Ringan-Ringan after his return from Malalo, but only inaugurated on March 28, 1961.

The establishment of this boarding school has been confirmed with a permit from the Religious Ministry of Indonesia Number M / 3 / SK / 1/05/12/1976, dated February 15, 1976 and on 13 April 1987 established the 
institutions that manages this boarding school, it is "Yayasan Pembangunaan Islam El Imraniyah (YPII)" by notarial deed Sjofyan Jonah. SH number 39.

Boarding schools typology in general divides into two forms, salafiah and khalafiah. Salafiyah boarding school is a traditional boarding school, while khalafiyah boarding school is called modern boarding school. Salafiyah are boarding schools that still retains the typical boarding school education system, both the curriculum, and methods of education, using the classical system or not. Teaching materials include the sciences of Islam by using the classical books in Arabic. While khalafiyah are boarding schools that adopt madrasah or school system, and the curriculum that is relevant to the government's curriculum, such as Religion Department or National Education Department. (Ministry of Religious Affairs, the Director General of the Directorate of Institutional Islamic Religious Education and Boarding School, 2002). Based on the typology of this boarding school, Nurul Yaqin is a category salafiyah or traditional boarding school.

As an educational institution, Nurul Yaqin Boarding School is a community-based education as stipulated in the Law on National Education System in article 1, paragraph 16. As also published in Education Law Article 30, paragraph 3 and 4 which explains the religious education can be organized in formal education , non-formal, and informal. Religious education can be devided into diniyah education, boarding school, pasraman, pabhaja samanera, and other forms. Under this law, in the administration of its education, Nurul Yaqin Boarding School has two forms of education, they are formal and non-formal education.

Formal Education in Nurul Yaqin is implemented in a tiered system and implemented classically. One of Nurul Yaqin Boarding School's documents described about the historical development of Nurul Yaqin Boarding School. On the other hand, the nonformal education, Nurul Yaqin Boarding
School educated the tarekat education to students and society. The tradition of tarekat education is still maintained until now and the implementation of the education is not done with the tiered system and classical. Nurul Yaqin Boarding School also has some religious traditions relate to Tarekat Syathariyyah. Local religious traditions (local Islamic) that most are not even found in the teachings of Abdurrauf Singkel as primary Syathariyyah teachers in the Indonesia. For example basapa tradition, salawat dulang, badikia, etc.

These traditions are an articulation of the "translation process" of Islam into the socio-cultural system, political and intellectual in a society which is basically the concept of a special and unique circumstances of a particular religious practice due to the local culture influenced, but also can occur because of the grounding of the normative teachings of Islam into reality. The integration of islam and local cultures can be its own cultural richness.

Maulid Nabi is also included an annual tradition at Nurul Yaqin. Maulid Nabi event was held after Isya praying, and usually ends after Ashar praying on the next day, the primary purpose is to remember the birthday of the Prophet Muhammad and build the feeling of love for him.

On this occasion, the area of Nurul Yaqin Boarding School crowded by jamaah and the students who study in this boarding school. Jamaah came from all regions. Typically, the ex students of Nurul Yaqin Boarding School after completing their education at this boarding school, partly founded surau and boarding. At the moment of Maulud Nabi event they came to Nurul Yaqin and carrying their jamaah and students. They also bought the donations for Maulid Nabi event. The donations are customarily in the form of money tied to the branches of small trees such as tree branches or flowers that have been stripped of their leaves first. In these branches bills the congregation donated tied. This donation is known as "Bungo Lado". According to Tuanku Krerajaan (February 9, 
2013), "Bunga Lado" relate to economic activities of society or jamaah in agriculture. Among the agricultural products is chili, in Minang it is called lado. This Chili or lado before fruiting, flowering its first. The more flower would be more fruit. In this case, the contribution of money is compared with the chilli's flower. Donations "Bunge Lado" is a symbol of gratitude for the blessings given by God in the hope God will multiply favors gift and reward of goodness.

In this Maulid Nabi event, all students involved as a committee to collect the donations from jamaah, welcoming and serving guests or jamaah. All guests are welcomed to come in and $\mathrm{h}$ are served a meal. Afterwards, jamaah who come would instantly see Buya Ali Imran as a form of homage to the teacher and continued to watch Shalawat dulang and badikia activities.

\section{Salawat Dulang}

Salawat dulang usually begins after Isya praying and will end at around two or three in the morning. Usually, at midnight, a lot of jamaah return to their homes. Unlike the badikia (berzikir), the activity is non-stop until the subuh time. After Subuh praying, the members of Dikia (zikir) will rest and eat in the morning until nine. After nine o'clock, dikia event will continue until the time of Zuhur. After lunch, dikia activities will be continued and closed after Ashar praying.

In order to observe the Salawat dulang, the author visits Nurul Yaqin Ringan-Ringan Boarding Schoool on the moment of Maulid Nabi on February 9, 2013, the author can see up close the salawat dulang activities. From the description of Tuanku Akmaluddin,one of the Maulid Nabi committees, all of groups that appear on the Maulid Nabi night are the people who have studied in boarding school, and some of them are still active as students. Tuanku Akmaluddin said that salawat dulang is not taught at the school. In fact, the teacher just teaching the study of tarekat,and the contents of salawat dulang is tarekat. They are good in showing the salawat dulang because of their own initiative to learn it to the people who are better in doing salawat dulang.

It can be believed that the students have initiative and motivation to learn salawat dulang because of the people's culture gives space for conservation of salawat dulang tradition. It can be seen by the performances of salawat dulang on the religious occasions such as Maulid Nabi, isra'mi'raj, even at the wedding reception.

According to Amir Adriyetti (1990: 5-24), salawat dulang is a medium used by Syekh Burhanuddin Ulakan in the propagation of Islam, especially in the teaching of Tarekat Syathāriyyah. Syekh Burhanuddin Ulakan got the inspiration for singing the teachings of Islam at the first time when he studied Islam in Aceh, and witnessed the Islamic teachings through pendendangan by using tambourine (rebana) (Oman Fathurrahman, 2008: 133).

When Burhanuddin returned to Minangkabau, according to Syamsir Roust (1998/1999: 42-43) quoted Fathurrahman, Burhanuddin was doing similar things, that is teachings Islam through pendendangan, but not using tambourine (rebana), meanwhile he used a dulang or talam. Dulang or talam is similar objects with nampan that made of brass, and is used for serving food. In West Sumatra,they usually consist of nasi lomak (ketan putih), nasi kunyik (nasi kunyit), wajik (hajit), gelamai, panyiaram, bulek-bulek, and others. All of them are called jamba. In general, the shape of salawat dulang is round circle with a diameter about $60 \mathrm{~cm}$. Flat middle section, while the perimeter edge of the lip has $3 \mathrm{~cm}$ height from the bottom, with a wide lip $3 \mathrm{~cm}$ (Oman Fathurrahman, 2008: 133).

According to Amir (1990: 5) quoted Fathurrahman (2008: 133) ,the showing of salawat dulang should be displayed in the mosque or surau, in a variety of religious and social events, such as Maulid Nabi, Isra Mi'raj, the inauguration of the mosque, the night before or after Khatam Al-Qur'ān in Ramadan, and others. 
There are two people that sing the salawat dulang,each of them holds a dulang, sitting cross-legged and tuck foot; one sitting on the right and left other. Both dulang placed on the right foot, left hand is placed on the upper edge of the dulang, while the right hand is placed on the bottom edge of the dulang. During singing the salawat, both of them usually move their head by turning to the left and to the right, as he squinted, and shouted to each other, so, no sound no pause in between (Oman Fathurrahman, 2008: 133).

Before becoming a "player", pendendang or the people who sing slawat, required to enter the Tarekat Syathāriyyah first, because the goal of salawat dulang is delivering the teachings of the tarekat, especially Tarekat Syathariyyah among the people in Minangkabau (Oman Fathurrahman, 2008: 133).

Thus, for the pendendang, salawa tdulang is not only an artistic activity, but more than that is the way to express their ritual tarekat. The verses are sung in salawat dulang was heavily laden with values of Sufism. And as already noted, the salawat dulang's verses also contain material "study" that is known among Syathāriyyah jamaah in West Sumatra as a "pengajian tubuh" (study of the body), beside the other themes such as advice to strengthen faith, stories about the afterlife, submission to the Creator, and others (Oman Fathurrahman; 2008: 133).

According to Amir (1990: 8), salawat dulang consists of three main components: first, katubah (Khutbah), which contains an opening, praise to Allah and the Prophet Muhammad, introduction, preamble for the lack of his group, and the introduction of what will be discussed (dibaco) in the next section; second, batang (main contents); and third, panutuik (penutup) (Oman Fathurrahman, 2008: 133).

Roust (1998/1999: 37-38) explains that a katubah, usually beginning with "imbauan katubah", or also called the "saruan" or appeal salawat, which aims as the opening, before it goes into "batang", usually preceded also by "imbauan lagu batang", which contains a preparation for the songs in the batang. At the beginning of the song, in this batang, dulang or talam are played (sounded) to accompany the verses recited poems. After the song in batang finish, pendendangan followed by Yamolai I, which also begins with an imbauan Yamolai I. Usually poem of Yamolai as a tribute to the venerable (like the Prophet Muhammad.). After that, pendendangan salawat dulang continued with Yamolai II, which was also preceded by an imbauan Yamolai II. After completing this Yamolai II, then pendendangan salawat dulang entry the part which generally liked by the audience, because it started to recite poems sung sufistis nuanced with various rhythm of the song (Oman Fathurrahman, 2008: 133).

Poems in salawat dulang was heavily influenced by the teachings tashawwuf and tarekat, especially Tarekat Syathāriyyah. Starting in katubah, various appeals (imbauan) in the context of tasawuf -which actually is a teaching in "high level" tarekat, because it is very nature filosofis- already started to be delivered. Katubah formulations are usually arranged in such a way, that also contains elements of praise, sarcasm, or teasing, addressed to the other groups that appear before or afterwards. Here is an example of salawat dulang verses which the transcription author quoted from Oman Fathurrahman's writing

(2008):

\section{Imbauan Khutbah}

\begin{tabular}{|l|l|}
\hline Aaa...ei...yo...oo....aa..ooo...aa...ei...ya & \\
\hline Aaa...ei...yo...aa...Nabi Allah o Na(nga)bi ... ya ... o ... ey & \\
\hline Aaayo junju(a)ngan & \\
\hline Aaayo junju(a)ngan & \\
\hline
\end{tabular}




\begin{tabular}{|l|l|}
\hline Allah Allah ei... & \\
\hline Allah Allah ei... & \\
\hline Aaayo junju(a)ngan & \\
\hline Aaayo junju(a)ngan & \\
\hline Aaa...ei...eieiei, Allah Allahurabbi, rabbi ya rabbi & $\begin{array}{l}\text { Allahurabbi our God, Nabi } \\
\text { Muhammad is our prince }\end{array}$ \\
\hline Allahurabbi baktuan kito, Nabi Muhammad pangulu kito & $\begin{array}{l}\text { Hello, friends,brothers and } \\
\text { sisters }\end{array}$ \\
\hline Wahai sahabat tolan sudaro & \\
\hline
\end{tabular}

\section{Khutbah}

\begin{tabular}{|c|c|}
\hline Assalamu'alaikum e tolan sahabat & Assalamu'alaikum friends,brothers, and sisters \\
\hline O jokalau kito kamangaji hakikat & If we would learn about hakikat \\
\hline Nyawa jo tubuah lah nyato sakabek & The soul and body are in a bundle \\
\hline Jangan disangko duo alamaik & Do not be mistaken for two addresses \\
\hline Kok disangko duo lah nyato sasek & If the two is obvious misguided \\
\hline Urang mandanga samonyo ingek & People hear all remember \\
\hline Urang aluma banyak nan kiramaik & Alumma people many sacred \\
\hline Janganlah kito bacando bodoh & Let us not be foolish \\
\hline Mumbang jo kalapo mano nan tuo & Which Pistil and coconut older is \\
\hline Anak jo bapo mano nan mudo & Which father and son younger is \\
\hline Kok tak ado anak bapo tak ado & If there is no child, neither father \\
\hline Zat jo sifat namo kajinyo & Zat and sifat the name of lesson \\
\hline Allah jo Muhammad di mano ko inyo & Where Allah and Muhammad are \\
\hline Di mano bana tampek nyatonyo & Where the right place in fact is \\
\hline Kok tidak dipaham di hati kito & If do not understand in our heaart \\
\hline Jalan nan samak kabatambah rimbo & Dirty road will increase the jungle \\
\hline Tak mungkin biawak kamalawan buayo & It is impossible the lizard againts alligator \\
\hline Tak mungkin babi kabaranak ruso & It is impossible the pig borns a deer \\
\hline Tak mungkin tumbuah tanduak di kudo & $\begin{array}{l}\text { It is impossible to grow horns on the head of a } \\
\text { horse }\end{array}$ \\
\hline Adapun raso jo na marasoi & As for the taste with tasted \\
\hline Baapo bana lilin jo api & How candle with fire \\
\hline Baapo bana cincin jo jari & How the ring with finger \\
\hline Nan mano bana nan sipaik maani & Which is the true of sifat Maani \\
\hline Iyo uju'am sipaik (a)kawi & Yes uju'am kawi's adjective \\
\hline Kok iyo mati sabalun mati & If you die before you die \\
\hline Tantukan jalan kakito lalui & Specify the path to be traversed \\
\hline Tantukan lauik kakito ranangi & Determine the ocean which will be swam \\
\hline Kubaklah kulik (i)lieklah isi & Peel off the skin look inside \\
\hline Supayo nak dapek bijo nan kawi & In order to seed the original \\
\hline Allahlah duduak di 'aras kursi & God was sitting in the 'aras chair \\
\hline Di kapalo jantuang Muhammad badiri & At the head of heart Muhammad stand \\
\hline Di panka jantuang sabuku darah mati & At the base of the heart, blood dies \\
\hline Di situ pulo(e) Abujaia badiri & There also Abujahil stand \\
\hline $\begin{array}{l}\text { Baparang jo Muhammad tak manaruah } \\
\text { habi }\end{array}$ & Fighting with Muhammad no stopping \\
\hline
\end{tabular}




\begin{tabular}{|l|l|}
\hline Kok kalah Muhammad narako dihuni & If Muhammad lose, go to hell \\
\hline Nagari Makah dimakan api & Mecca country engulfed in flames \\
\hline Kok manang Muhammad anggoto suci & If Muhammad are win, the members are holy \\
\hline Suci anggoto samo sakali & Holly members at alll \\
\hline Yo baitulah misanyo....aaa... & Yes so for example .... \\
\hline Yonan su...dalah tadiri yao... & Already composed \\
\hline
\end{tabular}

The second component of salawat dulang is "batang", which is a principal of tashawwuf teaching to be conveyed. For the group first performed, in addition to containing a variety of teaching tashawwuf, also contains the questions for the group that will appear in the next, on the contrary, "batang" of the next group is usually also contains the answers of questions from the first group, and so on. The verses of batang usually singing in the rhythm of the newest songs, like dangdut, or Minangkabau songs. Various improvisation in singing salawat dulang make this tradition still alive and preferably up to now (Oman Fathurrahman, 2008: 135).

In verses of salawat dulang, there are several important themes, such as the interpretation of zikir لااله الا الهـ, interpretation of the Hadits Nabi, which reads: "man 'arafa nafsah fa qad' arafa rabbah" ( who knows himself, then he will know his Lord ), ontological relationship of God and nature, which is analogous to the relationship of objects with his reflection in the mirror, as well as talks about $a^{\prime} y a n$ tsäbitah and $a^{\prime} y a n$ khārijiyyah. A'yan tsābitah is a term that in the context of tashawwuf defined as entities, archetypes, essences, or potential unchanging and infinity, which remains in nature. A'yan tsäbitah also means the picture names and the quality of Illahi and the core essence of knowledge with specific individualization. It means the essential nature of everything in azali time came from ilahi knowledge. All of it is set in accordance with the absence and not attributed to the presence (Armstrong 1996: 42). The mean of a'yan kharijiyyah is outside potential, or the creation of God in the real form, whose existence is derived from a'yan tsābitah (Azra 1994: 206).

In the last part of salawat dulang (penutup), the verses generally contains apology, thank you, as well as the messages that the material of "pengajian" has put forward can be beneficial to all. For the first groups to perform, part panutuik can also contain a request for the next group to answer the questions that have been posed. Here is an example of part panutuik of salawat dulang which is also taken from the transcription of Eden Binulia the author quotes from Oman Fathurrahman (2008: 139):

\section{The Closing of Shalawat Dulang}

\begin{tabular}{|l|l|}
\hline Iyo ala nde babari o kandak la de nan tibo & It has been given the will of arriver \\
\hline O de nan jo kok dari kami cukup lai sakian sajo & It is enough from us \\
\hline Iyo paneklah datang o litak nan lah tibo & Lelah (tired) come, capek (tired) arrived \\
\hline $\begin{array}{l}\text { O de nan kini baitulah de lai mangko na } \\
\text { kaeloknyo }\end{array}$ & Now it is better \\
\hline Iyo ala babari kandak nan tibo & \\
\hline Iyo kandak la de nan tibo iyo lai sabantah cako & Has been given the will of arriver \\
\hline O bak bumi nak sanang padi nak manjadi pulo & The requests coming at this moment \\
\hline Anak buah nak kambang nagari nak rami pulo & The peacefull in the world \\
\hline $\begin{array}{l}\text { Ala ibadat la de katuhan batambah-tambah la de } \\
\text { handaknyo }\end{array}$ & $\begin{array}{l}\text { The country will be crowded if there are } \\
\text { many students }\end{array}$ \\
\hline Dengan wassalam disudahi sajo & It is the end by wassalam \\
\hline
\end{tabular}




\section{Badikia}

Badikia or berzikir mean here is not the zikir tahlil, tahmid, or takbir. But badikia is the traditional procession by a group of people who deliberately to come on special occasions such as the Maulid Nabi. The contents of these badikia is praise, flattery, and blessings to Nabi Muhammad SAW. According to Tuanku Zakirman, badikia contents are taken from the Asyrafal Anam and Barzanji book which is sung in a high and shrill voice. If you notice, it is difficult to listen to what they are singing (dendangkan).

In spite of it all, the activity is aimed to breeding and birth anniversary of Nabi Muhammad SAW. According to Oman (2008:140), in the larger contect, salawat dulang and badikia also provide a real picture of what is often referred to as "local Islam", which is an articulation of the "translation process" of Islam into a social system budaya, political and intellectual force in a society (Hooker 1983). Local Islamic contains two important concepts. first, the concept of a special and unique circumstances of a particular religious practice. The uniqueness can be influenced by local culture, but also can occur because of the grounding of the normative teachings of Islam into reality; second, the element of local Islamic is an ongoing process of interaction between culture and Islam in the historical process.

Maulid Nabi, salawat dulang, badikia and various other forms of local rituals can be considered as a good example for the local Islamic. The integration of islam and local cultures can be its own cultural richness. It important to note that among the jamaah of the tarekat in Indonesia, not only Syathāriyyah, but also Rifa'iyyah, Qadiriyyah, Naqshbandiyya, Sammaniyah, etc. There are many local cultural expressions such as pencak silat, debus, and others. All this shows how rich the Indonesian Islam mosaic are (Oman, 2008: 140).

\section{CLOSING REMARKS}

Local Islamic culture consists of two important concepts. First, local Islam is the concept of a special and unique circumstances of a particular religious practice. The uniqueness can be influenced by local culture, but also can occur because of the grounding of the normative teachings of Islam into reality. Second, it contains elements of a local Islamic ongoing process of gathering and interaction of culture and Islam in the historical process.

Cultural values-based education can be interpreted as a manifestation of the culture internalization (internalized) which means to incorporate in oneself. Internalization is the process of teaching and cultivate a culture or value become self (self) the person concerned.

Education through local Islamic culture is needed by a community to born the resilience and ability of a group of people in acquiring the significance in their life.

\section{REFERENCES}

Algar, Hamid. (1980). The Study of Islam: The New Work of Henry Corbin, Religius Studies Review, Ontario, Canada: The Council on the Study of Religion

Azra, Azyumardi. (2002). Historiografi Islam Kontemporer: Wacana, Aktualitas, dan Aktor Sejarah. Jakarta: PT Gramedia Pustaka utama

Corbin, Henry. For the Concept of IranoIslamic Philosophy, The Philosophical Forum, Boston, 4/1

Departemen Agama RI. (2002). Dirjen Kelembagaan Agama Islam Direktorat Pendidikan Keagamaan dan Pondok Pesantren, Jakarta

Fathurrahman, Oman. (1999). Tanbīh alMāsyī; Menyoal Wahdatul Wujud, 
Kasus Abdurrauf Singkel di Aceh Abad 17

Fathurrahman, Oman. (2008). Tarekat Syathariyah di Minangkabau, (Jakarta: PPIM UIN Jakarta) Cet. 1

Furchan, Arief \& Maimun, Agus. (2005). Studi Tokoh; Metode Penelitian Mengenai Tokoh, Yogyakarta: Pustaka Pelajar

Jujun S \& Sumantri, Suria. (1988). Memperluas Cakrawala Penelitian Ilmiyah, Jakarta: IKIP Jakarta

Nata, Abuddin. (1997). Konsep Pendidikan Ibn Sina, (Disertasi). Jakarta: IAIN Syarif Hidayatullah

Nizar, Samsul. (2001). Hamka (1908-1981); Kajian Sosial-Intelektual dan Pemikirannya Tentang Pendidikan Islam (Disertasi), Jakarta: PPs Syarif Hidayatullah

P. Voorhoeve. (1980). Bayan Tajalli; Bahanbahan untuk Mengadakan Penyelidikan Lebih Mendalam tentang Abdurrauf Singkel, Banda Aceh: Pusat Dokumentasi dan Informasi Aceh.

Palmer, Richard, E. (2003). Hermeneutika; Teori Baru Mengenai Interpretasi, (Penj: Musnur Hery \& Damanhuri Muhammed, Judul Asli: Hermeneutics; Interpretation Theory in Schleimacher, Dilthey, Heidegger, and Gadamer, Northwestern Universiti Press, Evanston, 1969.), Yokyakarta: Pustaka Pelajar, Cet.3

Purippendolf, Klans. (1991). Analisis Isi: Pengantar Teori dan Metodologi. translated by Farid Wadji, Jakarta: Rajawali

Roust, Syamsir "Sejarah Perkembangan Selawat Talam sebagai Kesenian Islam di Sumatera Barat", laporan penelitian, Fakultas Adab, IAIN Imam Bonjol Padang. 1998/1999
Samad, Duski. (2003). Syekh Burhanuddin dan Islamisasi Minangkabau (Syarak Mandaki Adat Manurun), Padang: The Minangkabau Foundation atas Bantuan Yayasan Pengembangan Ekonomi dan Kesejahteraan Masyarakat Jakarta. cet. ke-2

Satori, Djama'an \& Komariah, Aan. (2010). Metodologi Penelitian Kualitatif, Bandung: Alfabeta.. cet. ke, 2

Sauri, Sofyan. Strategi Pengembangan Pendidikan berbasis Nilai Etika dan Budaya Dalam http://file.upi.edu/Direktori/FPBS/JUR. PEND.BAHASA ARAB/

Schimmel, Annemarie. (1997). Rahasia Wajah Suci Ilahi, penj: Rahmani Astuti, Bandung: Mizan

Stokes, Jane. (2006). How To Do Media and Cultural Studies; Panduan untuk Melaksanakan Penelitian dalam Kajian Media dan Budaya, Penj: Santi Ari Astuti. Yogyakarta: Bentang

Sugiyono. (2005). Memahami Penelitian Kualitatif, Bandung: Alfabeta

Sukardi. (2008). Metodologi Penelitian Pendidikan: Kompetensi dan Praktiknya, Jakarta: Bumi Aksara. cet. ke-6

Suprayogo, Irman \& Tobroni,. (2001). Metodologi Penelitian Sosial-Agama, Bandung: PT.Remaja Rosdakarya

Suyanto, Bagong \& Sutinah. (2005). Metode Penelitian Sosial; Berbagai Alternatif Pendekatan, Jakarta: Kencana. Cet I., h. 166

Tailor, Steven. J \& Bogdan, Robert. (1984). Intoduction to Qualitative Research Methods; thlme Search for Meaning. New York: Wiley \&Sons.Inc

Undang-undang Sistem Pendidikan Nasional No 20 tahun 2003 